Fadi Alfaqs, orcid.org/0000-0003-3427-6454, Ghazi S. Marahleh, orcid.org/0000-0003-4750-9245
Faculty of Engineering Technology, Department of Mechanical Engineering, Al-Balqa Applied University, Jordan, e-mail: faalfaqs@bau.edu.jo

\title{
FORCE AND PRESSURE FUNCTION FORMULATION FOR DIRECT COLD EXTRUSION OF ALUMINUM ALLOY AL 1350 USING REGRESSION METHOD
}

Purpose. Establishing methodology in order to determine mathematically both extrusion force and pressure functions for Aluminum alloy AL 1350 using the regression method of experimental data.

Methodology. Several variables (diameter of the cavity for pressing $D$, degree of extrusion, angle of the punch head cone $2 \delta$, and ratio of the semi-finished sizes $R_{s}$ ) were included when using the regression method considered.

Findings. Diameter and strain were found to play a significant role in predicting both extrusion force and pressure functions associated with the extrusion process. Mathematical formulas for force and pressure were obtained using the regression method. A methodology has been developed for the mathematical determination of extrusion force and pressure.

Originality. Force and pressure functions in direct cold extrusion process are mainly required for the design of extrusion dies. However, the existence of such data in the literature is insufficient to implement the process for direct cold extrusion of aluminum and aluminum alloys as well as for other materials. Results of the study consider the main factors influencing extrusion force and pressure as well as the main differences for types of aluminum alloys.

Practical value. The mathematical formulas obtained by the regression method provide a mathematical tool for calculating force and pressure values in direct extrusion process.

Keywords: aluminum alloy, direct extrusion, force, pressure, regression

Introduction. Effect of different types of lubricants on extrusion force in cold extrusion process was studied experimentally and numerically [1], where it is found that strain rates affect the extrusion force significantly, that is, increasing strain rate leads to force increase for all cases considered in the study.

However, a finite element model was developed for a cold forward extrusion process to investigate temperatures, stress, and strain during the process considered in both the die and the punch [2]. Results were compared to experimental data in order to verify the finite element results where excellent agreement was observed.

Influence of cold extrusion of pure copper was investigated and evaluated on stress-strain diagram using cosine velocity model [3]. A finite element model was developed to verify the stress-strain experimental data. It was found that values of stress obtained were less in current model than constant velocity model.

However, a study concerning nine geometrical parameters of drive shaft was conducted using 3-D finite element modeling [4]. It should be said that the drive shaft considered consists mainly of spur gear and spline. The results showed that both shoulder angles should be $45^{\circ}$ as a dimensional requirement.

A parameter investigation of internal thread cold extrusion was presented to select the process parameters accurately using numerical simulations [5]. It is found that both torque and temperature during the extrusion process were reduced in addition to quality improvement compared to other selection criteria.

Furthermore, a new approach for cold extrusion using dimple indentation was proposed [6]. Also, lubrication process was performed using palm oil. The results obtained showed that using such an approach reduced cold extrusion force as well as surface roughness for the product.

Effect of temperature on the behavior of copper microextrusion was investigated for elevated temperature up to $200{ }^{\circ} \mathrm{C}$ [7]. It is found that increasing temperature led to copper flowing more uniformly. Moreover, microhardness readings showed reduction trend compared to hardness test for the same material.

Cold extrusion effective stress in longitudinal sections was studied using finite element modeling [8]. It should be said that different punch face shapes such as flat and conical shapes

(C) Fadi Alfaqs, Ghazi S. Marahleh, 2021 were implemented during simulation where the numerical results presented in the work showed that maximum flow stress was obtained at the last stages for all shapes considered.

Several variables affecting stress corrosion of aluminum alloys were investigated using different environmental circumstances [9]. It is found that direction cracks formed during tests differ from expected results.

Mathematical model was developed to study different parameters affecting aluminum hollow cylindrical casting [10]. As a result, parameter calculations of cylindrical elements can be calculated for design stages.

Shape parameters' influence on Aluminum cold extrusion products was investigated experimentally [11]. Furthermore, a numerical model was developed to verify the data recorded during experimental work. The results showed that extrusion ratio and symmetry of die profile are the most important factors affecting the final product.

Effect of temperature associated with the extrusion process of Aluminum AA6060 on mechanical behavior is studied experimentally [12]. It is found that temperature under recrystallization led to high strength where optimum temperature was recorded at $120^{\circ} \mathrm{C}$, which produced high ductility as well.

However, influence of several lubricants on temperature distribution was presented in backward cold extrusion process [13] where higher temperature of the punch was recorded for all cases considered. Also, the results obtained via simulation showed good agreement with experimental results.

Manufacturing of cold extruded Aluminum was investigated to determine its mechanical properties and test its spring microstructure [14]. The research revealed that using lubricants during the extrusion process would enhance spring fatigue life.

Properties of processed materials. Three semi-finished alloy samples of aluminum 1350 for different alloy compositions were considered during the experimental procedure, where chemical analysis is performed to determine percentages of impurities ( $\mathrm{Mg}, \mathrm{Si}, \mathrm{Cu}, \mathrm{Mn}, \mathrm{Zn}, \mathrm{Fe}, \mathrm{Ni}$, and Ti) in each alloy sample considered as listed in Table 1.

It is clearly noted that percentage of aluminum in each alloy is $99.5 \%$ as other impurities form together $0.5 \%$. However, chemical composition results were compared to STAS as shown in the table considered.

Furthermore, several experimental mechanical tests were conducted to obtain the hardness of each alloy sample consid- 
Chemical composition of three different alloy samples compared to STAS

\begin{tabular}{|c|c|c|c|c|c|c|c|c|c|c|}
\hline & \multirow{2}{*}{$\mathrm{Al}, \%$} & \multicolumn{9}{|c|}{ Impurities, $\%$ max. } \\
\hline & & $\mathrm{Mg}, \%$ & $\mathrm{Si}, \%$ & $\mathrm{Cu}, \%$ & $\mathrm{Mn}, \%$ & $\mathrm{Zn}, \%$ & $\mathrm{Fe}, \%$ & $\mathrm{Ni}, \%$ & $\mathrm{Ti}, \%$ & Others, \% \\
\hline STAS & 99.5 & - & 0.30 & 0.02 & - & 0.07 & 0.40 & - & 0.03 & 0.5 \\
\hline 1 & 99.5 & 0.02 & - & $0.12^{*}$ & 0.03 & 0.04 & 0.2 & 0.03 & - & 0.06 \\
\hline 2 & 99.5 & 0.10 & 0.15 & $0.03^{*}$ & 0.02 & 0.03 & 0.02 & 0.02 & - & 0.13 \\
\hline 3 & 99.5 & 0.01 & 0.15 & 0.01 & 0.01 & 0.03 & 0.2 & 0.03 & 0.02 & 0.07 \\
\hline
\end{tabular}

*values that exceed the maximum limits established by STAS

ered previously, where the results of experimental hardness measurements are shown in Table 2 . It is clearly observed that maximum average hardness of HB 32.76 was recorded for sample 2 while, on the other hand, minimum hardness was obtained as HB 32.33 for sample 3. It should be said that alloy tensile strength is directly proportional to hardness. Hence, sample 2 was chosen.

However, several preparatory operations were made prior to experimental procedure. First, parts were formed by cutting sheet metal stripes. Then, passivation was performed by maintaining the parts considered in a solution consisting of $150 \mathrm{~L}$ of water, $150 \mathrm{~kg}$ chromic anhydride $\left(\mathrm{CrO}_{3}\right), 30 \mathrm{~L}$ of sulphuric acid $\left(\mathrm{H}_{2} \mathrm{SO}_{4}\right)$, and $20 \mathrm{~L}$ nitric acid $\left(\mathrm{HNO}_{3}\right)$ for $8-10$ minutes. Furthermore, thermal treatment was performed using annealing process by heating the parts in furnace up to $450{ }^{\circ} \mathrm{C}$ which is maintained for 4 hours, followed by air cooling. It should be mentioned that the lubrication process was made by involving approximately 30000 parts with a diameter of $6-20 \mathrm{~mm}$ and 5-6 thickness together with $300 \mathrm{~g}$ of zinc stearate for 30 minutes.

Form of experimental functions and programs. A mathematical model of cold extrusion, like any technological process, can be performed by establishing quantitative relationships between several independent variables affecting the process. Force and pressure process functions are, in general, modeled using several independent variables (rarely with a single variable) and in this case, their implementation, based on experimental research, is performed by statistical coding of experiments using the method of surface regression. Current method consists of statistical programming of samples' data obtained experimentally, analysis of scattering and regression rules in mathematical statistics, and simultaneous variation in experiments of independent variables taking a fixed number of values called levels of variation.

Regression functions of polynomial or trigonometric type (of different orders) are obtained using several independent variables. Although the independent variables are varied simultaneously, their separate effect can be quantitatively evaluated, and - consequently - the terms of the model with insignificant influence can be excluded. However, should the number of experiences increase, mathematical model accuracy increases as well. It should be said that not only current method is used for cold extrusion, but also it can be used for plastic deformation processes.

The use of the method in experimental research for determining the process functions requires the accomplishment of the following stages:

Table 2

Experimental hardness results for the three samples considered

\begin{tabular}{|c|c|c|c|c|}
\hline \multirow{2}{*}{ Sample } & \multicolumn{3}{|c|}{ HB HARDNESS } & \multirow{2}{*}{ Average HB } \\
\cline { 2 - 4 } & 1 & 2 & 3 & HARDNESS \\
\hline 1 & 33.6 & 32.2 & 32.2 & 32.66 \\
\hline 2 & 33.5 & 32.4 & 32.4 & 32.76 \\
\hline 3 & 32.4 & 31.8 & 32.8 & 32.33 \\
\hline
\end{tabular}

1. The choice of the form and complexity of the mathematical model.

2. Statistical programming of experiments considering all experimental conditions.

3. Knowledge of the means necessary for research and performance experiences.

4. Determining the deficiencies of the function-regression (model).

5. Verifying the significance of the coefficients and the reliability of the considered mathematical model.

6 . Establishing the confidence intervals $(95 \%)$ for the determined coefficients.

7. Total experimental values of the independent variables (influence factors) $X_{i j}$ and the dependent variable $Y_{j}$, where $i=$ $=1,2, \ldots, k(k-$ the total number of independent variables $)$ and $j=1,2, \ldots, n$ ( $n-$ the number of experiments) are the experimental data that serve to determine the process function.

Among multiple cases that are considered when establishing the regression is that of the calculation of regression coefficients performed by the least square method either of polynomial or trigonometric formats. However, the following formulas are commonly used

$$
\begin{gathered}
Y=A_{0}+A_{1} X_{1}+A_{2} X_{2}+\ldots ; \\
Y=A_{0} X_{1}^{A_{1}} X_{2}^{A_{2}} \cdots
\end{gathered}
$$

However, polynomial of the following form is considered in the case of complex processes with $\mathrm{k}$ independent variables by approximation using Taylor series formula

$$
y=a_{o}+\sum_{1}^{k} a_{i} z_{i}
$$

Or

$$
y=a_{o}+\sum_{1}^{k} a_{i} z_{i}+\sum_{1}^{k-1} \sum_{i+1}^{k} b_{i j} z_{i} z_{j}+\sum_{1}^{k} b_{i i} z_{i}^{2}+\ldots,
$$

where $y=\ln Y ; z_{j}=\ln X ; i=1,2, \ldots, k ; j=1,2, \ldots, n$.

It is recommended that all the parameters assumed to influence the process be considered in the tests where the order of the mathematical model considered is the highest order of any term existing in the formula. However, if the order of the model is higher than necessary, then by checking the significance of the coefficients, the coefficients of the higher order terms are insignificant and these terms are eliminated.

In order to determine the coefficients of the process function using the experimental data, the least squares method is applied since coefficients are obtained with the highest accuracy. It is denoted by $y_{i} ; \tilde{y}_{i} ; i=1,2, \ldots, n$.

Where $y_{i}$ - are the values of the variable dependents obtained experimentally and $\tilde{y}_{i}$ - values of the variables determined by the calculation with the expression in equation (4). However the term $\left(\tilde{y}_{i}-y_{i}\right)$ is called the residual or regression deviation denoted by $r z$. The sum of the residual squares is 


$$
\begin{gathered}
\sum_{1}^{n}\left(\tilde{y}_{i}-y_{i}\right)^{2}= \\
=\sum_{i=1}^{n}\left(b_{o}+\sum_{i=1}^{k} b_{i} x_{i}+\sum_{i=1}^{k-1} \sum_{j=i+1}^{k} b_{i j} x_{i} x_{j}+\sum_{i=1}^{k} b_{i i} x_{i}^{2}+\ldots-y_{i}\right)^{2} .
\end{gathered}
$$

The least square method imposes the condition that the sum of the residual squares is minimal, a condition that is satisfied by the solutions of the system of linear equations obtained by canceling the derivatives of the sum of their squares in relation to all the coefficients. To obtain the coefficients of the model with natural variables, each variable is replaced in the model with coded variables.

The assessment of the deviations of the dependent variables measured from those calculated and with the function determined for each exponent from the experimental program is made with the help of the relative error relation

$$
\epsilon_{y_{i}}=\frac{y_{i}-\tilde{y}_{i}}{\tilde{y}_{i}} \cdot 100 \%
$$

In the present work, three different experimental pressure formulas containing several parameters were proposed in order to describe the force in extrusion process during regression method implementation. It should be mentioned that function 1 consists of four independent parameters; $D, \in, 2 \delta$, and $R_{s}$ whereas function (2) and function (3) are formulated using three $\left(D, \in\right.$, and $\left.R_{s}\right)$ and two ( $D$ and $\in$ ) independent parameters. It should be observed that the independent parameters considered are shown in Figs. 1, 2.

Where $D$ is diameter of the cavity for pressing the active plate, $\mathrm{mm} ; \in$ is the extrusion strain $=1-d^{2} / D^{2} \cdot 100 \% ; d$ is the billet diameter which is the diameter of the calibration hole, $\mathrm{mm} ; 2 \delta$ is an angle of the punch head cone, degrees; $R_{S}$ is the ratio of the semi-finished sizes $R_{S}=100 H_{O} / D_{O}, \%$, where $H_{O}$ is the semi-finished sample thickness; $D_{O}$ is the semi-finished sample diameter, $D_{O}=D-0.2 \mathrm{~mm}$.

It should be said that three different mathematical formulas were developed for force and pressure prediction as listed in Table 3. Moreover, for $(1,2)$ considered, two sets of experiments were conducted containing 12; 20 and 12; 18 experiments re-

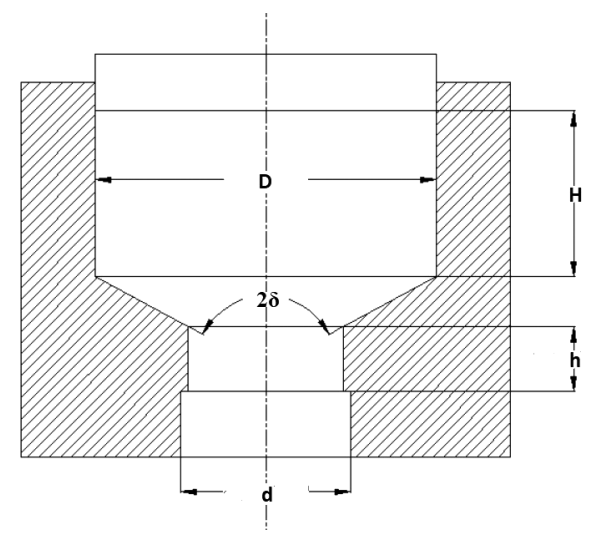

Fig. 1. Direct extrusion for solid parts

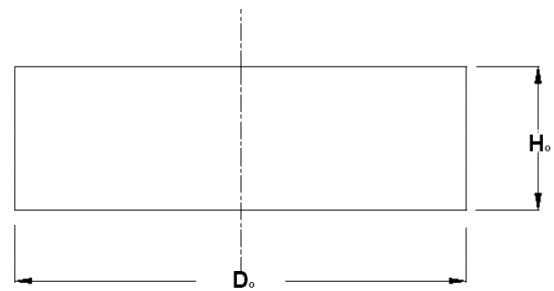

Fig. 2. Semi-finished samples used in direct extrusion process spectively, whereas six experiments were established for (3). This is reasonable since solving formulas containing more parameters as in $(1,2)$ (4 and 3 independent parameters respectively) needs conducting more experiences in order to obtain reliable parameters values. Such a number of experiments is also necessary to analyze the influence of each independent variable on the adequacy of the function pattern, the significance of coefficients, relative errors of the values calculated as compared to those measured and on the confidence interval of $95 \%$.

The levels of variation and their values for the independent variables of process functions are mentioned in Table 4 .

The determination of the process function model, with a multiplicative approximation is possible if the experiments are performed in a certain number and with certain combinations of independent variables where statistical programming of experiments is used, providing the data necessary for regression analysis.

Determining the coefficients and statistical analysis of the function model is easier if the values and levels of variation of independent variables are coded as listed in Table 4, where

Table 3

\begin{tabular}{|c|c|c|c|c|}
\hline \multicolumn{2}{|r|}{ Process Function } & \multicolumn{3}{|c|}{ Experimental program } \\
\hline No. & Formula & $\begin{array}{l}\text { Program } \\
\text { used }\end{array}$ & 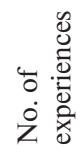 & 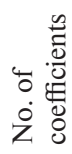 \\
\hline \multirow[t]{2}{*}{1} & $p=A_{O} D^{A 1} \in{ }^{A 2}(2 \delta)^{A 3} R_{S}^{A 4}$ & \multirow[t]{2}{*}{ P4; P5 } & \multirow[t]{2}{*}{$12 ; 20$} & \multirow[t]{2}{*}{5} \\
\hline & $\begin{array}{l}\ln p=\ln A_{O}+A_{1} \ln D+\mathrm{A}_{2} \ln \in+ \\
+A_{3} \ln (2 \delta)+A_{4} \ln R_{S}\end{array}$ & & & \\
\hline \multirow[t]{2}{*}{2} & $p=A_{O} D^{A 1} \in{ }^{A 2} R_{S}^{A 3}$ & \multirow[t]{2}{*}{ P2; P3 } & \multirow[t]{2}{*}{$12 ; 18$} & \multirow[t]{2}{*}{4} \\
\hline & $\begin{array}{l}\ln p=\ln A_{O}+A_{1} \ln D+A_{2} \ln \in+ \\
+A_{3} \ln R_{S}\end{array}$ & & & \\
\hline \multirow[t]{2}{*}{3} & $p=A_{O} D^{41} \in^{A 2}$ & \multirow[t]{2}{*}{ P1 } & \multirow[t]{2}{*}{6} & \multirow[t]{2}{*}{3} \\
\hline & $\ln p=\ln A_{O}+A_{1} \ln D+A_{2} \ln \in$ & & & \\
\hline
\end{tabular}

Experimental functions used with experiences and the number of coefficients used

Note: The same forms have the functions-force and extrusion, changing letter $\mathrm{p}$ by letter $\mathrm{F}$

\begin{tabular}{|c|c|c|c|c|}
\hline \multirow{4}{*}{ Independent variables } & \multicolumn{4}{|c|}{ Annotation for levels } \\
\hline & \multirow[t]{2}{*}{ 잉 } & 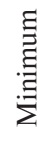 & 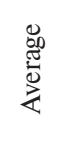 & 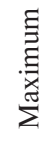 \\
\hline & & -1 & 0 & +1 \\
\hline & 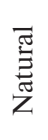 & 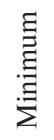 & 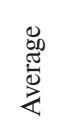 & 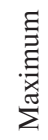 \\
\hline $\begin{array}{l}\text { Diameter of the cavity for pressing the } \\
\text { active plate, } \mathrm{mm}\end{array}$ & $D$ & 9.6 & 14 & 20 \\
\hline $\begin{array}{l}\text { Extrusion degree } \varepsilon=1-d^{2} / D^{2} \cdot 100 \% \text {, } \\
\text { where } \mathrm{d} \text { is the diameter of the calibration } \\
\text { hole }\end{array}$ & $\varepsilon$ & 36 & 50 & 70 \\
\hline Angle of the punch head cone, degrees & $2 \delta$ & 125 & 150 & 180 \\
\hline $\begin{array}{l}\text { Ratio of the semi-finished sizes } R_{S}= \\
100 H_{O} / D_{O}, \% \text {, where } H_{O} \text { is the thickness } \\
\text { and } D_{O}=D-0.2 \mathrm{~mm} \text { diameter }\end{array}$ & $R_{S}$ & 40 & 48 & 58 \\
\hline
\end{tabular}

Table 4

Independent parameters variations 
$X_{i} \max =+1 ; \quad X_{i} \min =-1 ; \quad X_{i} \operatorname{mid}=0$.

However, P1, P2, P3, P4, and P5 present Fractional factor programs used in regression method. It should be said that if the number of independent variables increases, the number of experiences increases. Moreover, the statistical analysis of the model requires that experimental program considered also contain a number of repeated experiments that are taken into the center of the field. The values of these experiments are used to determine the experimental error and are called central points. Furthermore, it is clearly seen that two levels of variation are used for each of the four parameters considered $(D, \in$, $2 \delta$, and $R_{\mathrm{s}}$ ). However, as can be observed from Table 4, variations for diameter $D$, extrusion degree $\varepsilon$, angle of the punch head cone $2 \delta$, and ratio of the semi-finished sizes $R_{S}$ are set to 9.6, 14, and $20 \mathrm{~mm}, 36,50$, and 70, 125, 150, and 180 degrees, and $40,48,58 \mathrm{~mm}$ respectively.

Means for conducting experiments. All experiments were carried out using a hydraulic press, using a torque table and an extruder die with a relatively rapid change in the active parameters. The stand was completed with a sphygmomanometer and watt metric kit for measuring the consumed power. The scheme of the stand is presented in Fig. 3. The punches and active plates were executed with the forms and sizes of the active areas according to the experimental programs.

The case is studied when the machined parts are pressed through a frustoconical zone of passage depending on the value of the angle $2 \delta<180^{\circ}$. It should be said that the semi-finished product is cylindrical (bar or pellet type - depending on length and thickness), when the active plate is inserted into the pressing cavity.

Results. All experimental data were recorded by measuring direct extrusion force for 28 experiments as shown in Table 5, where the pressure was calculated by relating force to

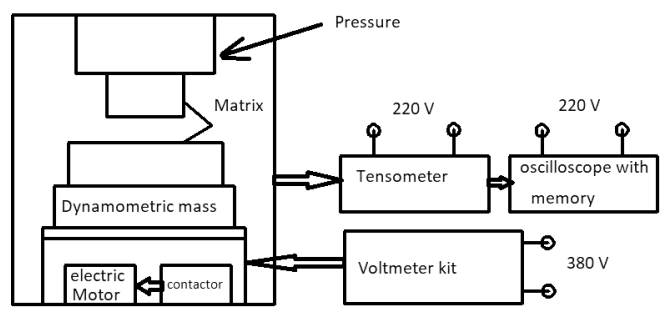

Fig. 3. Scheme of stand used in experimental work

Table 5

Force and pressure experimental results for different values of independent variables

\begin{tabular}{|c|c|c|c|c|c|c|c|c|}
\hline \multirow{3}{*}{$\begin{array}{c}\text { No. of } \\
\text { experiment }\end{array}$} & \multirow{3}{*}{$\begin{array}{c}\text { Program } \\
\text { code/ } \\
\text { Experiences }\end{array}$} & \multicolumn{7}{|c|}{ Direct extrusion } \\
\hline & & \multicolumn{4}{|c|}{ Independent variables } & \multicolumn{3}{|c|}{ Force pressure } \\
\hline & & $D(\mathrm{~mm})$ & $\varepsilon, \%$ & $2 \delta$ (degree) & $R_{S,} \%$ & Divisions & $F(N)$ & $P\left(N / \mathrm{mm}^{2}\right)$ \\
\hline 1 & $\mathrm{P} 1 / 1$ & 9.6 & 36 & 125 & 40 & 0.35 & 14745.2 & 203.6 \\
\hline 2 & $\mathrm{P} 3 / 1$ & 9.6 & 36 & 150 & 40 & 0.37 & 15158.4 & 209.4 \\
\hline 3 & $\mathrm{P} 3 / 5$ & 9.6 & 36 & 150 & 58 & 0.41 & 15982.4 & 220.7 \\
\hline 4 & P $1 / 5$ & 9.6 & 36 & 180 & 58 & 0.405 & 15888.0 & 219.4 \\
\hline 5 & P $1 / 9$ & 9.6 & 50 & 150 & 48 & 0.60 & 19857.7 & 274.3 \\
\hline 6 & $\mathrm{P} 1 / 3$ & 9.6 & 70 & 125 & 58 & 0.80 & 23451.8 & 324.0 \\
\hline 7 & P $3 / 3$ & 9.6 & 70 & 150 & 40 & 1.10 & 29746.6 & 410.8 \\
\hline 8 & P $3 / 7$ & 9.6 & 70 & 150 & 58 & 1.15 & 30710.8 & 424.2 \\
\hline 9 & P 1/7 & 9.6 & 70 & 180 & 40 & 1.15 & 30710.8 & 424.2 \\
\hline 10 & $\mathrm{P} 1 / 11$ & 14 & 36 & 150 & 48 & 0.90 & 25844.8 & 167.8 \\
\hline 11 & $\mathrm{P} 1 / 13$ & 14 & 50 & 125 & 48 & 1.30 & 33576.6 & 218.0 \\
\hline 12 & $\mathrm{P} 1 / 15$ & 14 & 50 & 150 & 40 & 1.40 & 35464.6 & 230.3 \\
\hline 13 & P $1 / 17$ & 14 & 50 & 150 & 48 & 1.42 & 35840.1 & 232.8 \\
\hline 14 & $\mathrm{P} 1 / 18$ & 14 & 50 & 150 & 48 & 1.37 & 34980.6 & 227.2 \\
\hline 15 & P $1 / 19$ & 14 & 50 & 150 & 48 & 1.37 & 34980.6 & 227.2 \\
\hline 16 & $\mathrm{P} 1 / 20$ & 14 & 50 & 150 & 48 & 1.43 & 36027.6 & 236 \\
\hline 17 & $\mathrm{P} 1 / 16$ & 14 & 50 & 150 & 58 & 1.42 & 35840.1 & 232.4 \\
\hline 18 & $\mathrm{P} 1 / 14$ & 14 & 50 & 180 & 48 & 1.52 & 37468.5 & 243.4 \\
\hline 19 & $\mathrm{P} 1 / 12$ & 14 & 70 & 150 & 48 & 2.36 & 52759.2 & 342.6 \\
\hline 20 & $\mathrm{P} 1 / 2$ & 20 & 36 & 125 & 58 & 2 & 46411.2 & 147.7 \\
\hline 21 & P $3 / 2$ & 20 & 36 & 150 & 40 & 1.9 & 44636.1 & 142 \\
\hline 22 & P $3 / 6$ & 20 & 36 & 150 & 58 & 2.05 & 47300 & 150.6 \\
\hline 23 & $\mathrm{P} 1 / 6$ & 20 & 36 & 180 & 40 & 2.25 & 50789 & 161.6 \\
\hline 24 & $\mathrm{P} 1 / 10$ & 20 & 50 & 150 & 48 & 3 & 63235.1 & 201.2 \\
\hline 25 & $\mathrm{P} 1 / 4$ & 20 & 70 & 125 & 40 & 4.55 & 85759.7 & 272.9 \\
\hline 26 & P $3 / 4$ & 20 & 70 & 150 & 40 & 4.85 & 89621.7 & 285.2 \\
\hline 27 & P $3 / 8$ & 20 & 70 & 150 & 58 & 4.9 & 90249.5 & 287.2 \\
\hline 28 & P $1 / 8$ & 20 & 70 & 180 & 58 & 4.95 & 90873.1 & 289.2 \\
\hline
\end{tabular}


Mathematical relation produced by regression method

\begin{tabular}{|c|c|c|c|}
\hline $\begin{array}{c}\text { Program } \\
\text { No./No. } \\
\text { of experiment }\end{array}$ & The function for direct extrusion & $\begin{array}{c}\text { Limits of relative } \\
\text { error } \%\end{array}$ & $\begin{array}{c}\text { Function } \\
\text { No. }\end{array}$ \\
\hline $\mathrm{P} 5 / 20$ & $\ln F=0.659+1.606 \ln D+0.925 \ln \varepsilon+0.305 \ln (2 \delta)-0.141 \ln R_{S}$ & $\begin{array}{c}+7.33 \ldots \\
-6.49 \\
(14 \text { errors }< \pm 3 \%)\end{array}$ & 1 \\
\hline $\mathrm{P} 3 / 18$ & $\ln \mathrm{F}=2.241+1.500 \ln D+1.0811 n \varepsilon+0.086 \ln R_{S}\left(\right.$ in the case of $\left.(2 \delta)=150^{\circ}\right)$ & $\begin{array}{c}+4.68 \ldots \\
-5.90 \\
(11 \text { errors }< \pm 3 \%)\end{array}$ & 2 \\
\hline $\mathrm{P} 1 / 6$ & $\ln F=2.561+1.487 \ln D+1.0311 n \varepsilon+\left(\right.$ in the case of $2 \delta=150^{\circ}$ and $\left.R_{S}=40 \%\right)$ & $\begin{array}{c}+2.36 \ldots \\
-3.15 \\
(4 \text { errors }< \pm 1 \%)\end{array}$ & 3 \\
\hline P5/20 & $\ln p=1.760-0.406 \ln D+0.912 \ln \varepsilon+0.330 \ln 2 \delta-0.116 \ln R_{S}$ & $\begin{array}{c}+6.58 \ldots \\
-5.65 \\
(9 \text { values }< \pm 3 \%)\end{array}$ & 4 \\
\hline $\mathrm{P} 3 / 18$ & $\ln p=2.476-0.500 \ln D+1.0181 n \varepsilon+0.086 \ln R_{S}\left(\right.$ in the case of $\left.2 \delta=150^{\circ}\right)$ & $\begin{array}{c}+5.51 \ldots \\
-5.47 \\
(7 \text { values }< \pm 3 \%)\end{array}$ & 5 \\
\hline $\mathrm{P} 1 / 6$ & $\ln p=2.796-0.513 \ln D+1.031 \ln \varepsilon\left(\right.$ in the case of $2 \delta=150^{\circ}$ and $\left.R_{S}=40 \%\right)$ & $\begin{array}{c}+1.44 \ldots \\
-4.59 \\
(3 \text { errors }< \pm 1.04 \%)\end{array}$ & 6 \\
\hline
\end{tabular}

the frontal contact surface between the punch and the semifinished product. It should be said that the input data (independent variables) are expressed using several variables; diameter of the cavity for pressing $D$, degree of extrusion, angle of the punch head cone $2 \delta$, and ratio of the semi-finished sizes $R_{s}$ ).

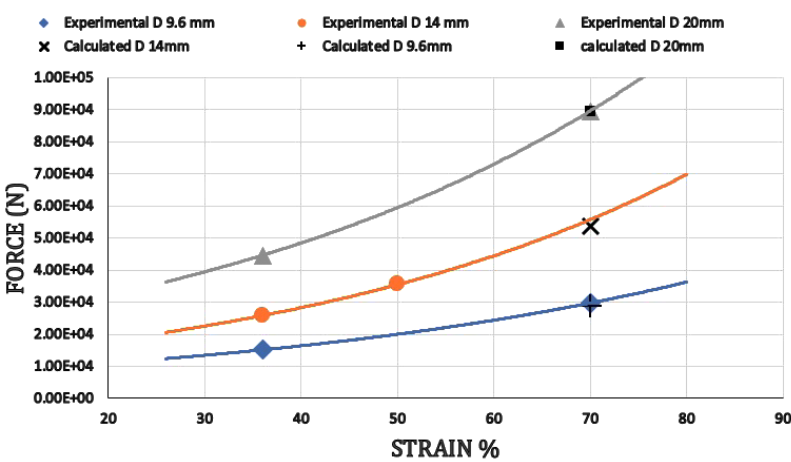

Fig. 4. Comparison of force experimental data with calculated results (at $\left.\varepsilon=70 \% ; 2 \delta=150^{\circ} ; R_{s}=70 \%\right)$

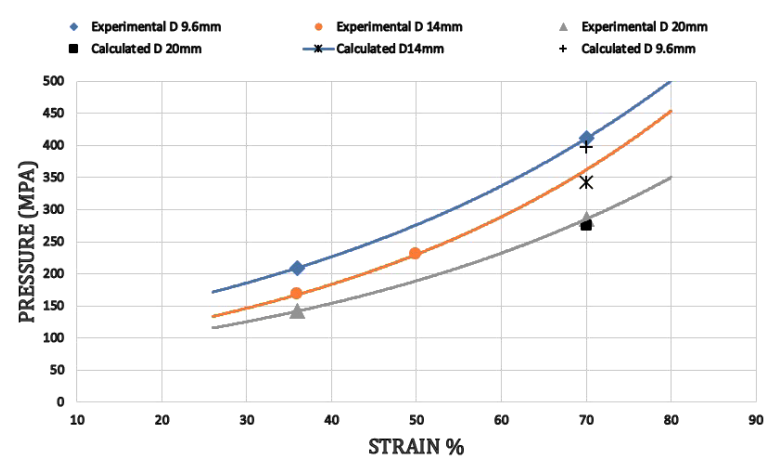

Fig. 5. Comparison of pressure experimental data with calculated results (at $\left.\varepsilon=70 \% ; 2 \delta=150^{\circ} ; R_{s}=70 \%\right)$
Based on the experimental formulas presented in Table 3, six process functions for force and pressure were determined as presented in Table 6 using fractional factor programs mentioned where it is found that the process functions determined with the data according to program $\mathrm{P} 4$ turned out inadequate. On the other hand, it should be mentioned that variable $R_{S}$ is found to be insignificant when examining process functions $(2,3,4$, and 5). Furthermore, it is clearly seen that the value of relative error of each of the process functions obtained is less than $3 \%$.

However, Figs. 4 and 5 illustrate the effect of extrusion angle $\varepsilon$ on force and pressure respectively for various values of diameter $D(9.6,14$, and $20 \mathrm{~mm})$ at the head cone angle of $150^{\circ}$ and ratio of semi-finished sizes $R_{S}$ of $40 \%$. It is clearly observed that both force and pressure increase if the extrusion angle increases at certain values diameter $D$. Moreover, it is clearly seen that maximum pressure is obtained for the diameter of $9.6 \mathrm{~mm}$. This is reasonable since pressure is inversely proportional to the area. The force and pressure calculated using the functions developed were illustrated in the two figures considered for different diameters at extrusion angle $\varepsilon$, head cone angle $2 \delta$, and ratio of semi-finished sizes $R_{S}$ of 70,150 , and $40 \%$ respectively where excellent agreement was found.

Conclusion. Pressure and force functions of direct extrusion process are determined using the regression method according to a scientific, completely established methodology using five programming codes, where it is found that the main influential factors for direct cold extrusion force and pressure respectively are diameter $D$ and extrusion degree $\varepsilon$. On the other hand, the angle $2 \delta$ and the ratio $R_{S}$ were less significant.

Relative errors between the values calculated with the determined functions and the experimentally measured values are found to be very low having values below $3 \%$ in most cases. This can be clearly observed in Figs. 4 and 5 for force and pressure respectively.

Process functions obtained using regression method complete the data bank for designing technologies and direct cold extrusion moulds in the case of processing aluminum $\mathrm{Al} 1350$. 


\section{References.}

1. Oyinbo, S., Ikumapayi, O., Jen, T., \& Ismail, S. (2020). Experimental and numerical prediction of extrusion load at different lubricating conditions of aluminium 6063 alloy in backward cup extrusion. Engineering Solid Mechanics, 8(2), 119-130. https://doi.org/10.5267/j. esm.2019.10.003.

2. Luca, D., Slătineanu, L., Merticaru, V., Mihalache, A. M., Dodun, O., Ripanu, M. I., ..., \& Panait, C. E. (2018). Finite element simulation and experimental investigation of cold forward extrusion process. MATEC Web of Conferences, 178, 02010. https://doi.org/10.1051/ matecconf/201817802010.

3. Huang, S.H., Wu, Y., Xia, X.S., Zhao, Z.D., Chen, Q., \& Shu, D. Y. (2019). Assessment of Cold Extrusion Effect on StressStrain Curves of Pure Copper Arc Parts Based on the Cosine Velocity Model. Strength of Materials, 51(4), 569-577. https://doi.org/10.1007/ s11223-019-00102-8

4. Ku, Tae-Wan (2020). A Combined Cold Extrusion for a Drive Shaft: A Parametric Study on Tool Geometry. Materials, 13(10), 2244. https://doi.org/10.3390/ma13102244.

5. Hou, H.-L., Zhang, G.-P., Xin, Ch., \& Zhao, Yo.-Q. (2020). Numerical Simulation and Process Optimization of Internal Thread Cold Extrusion Process. Materials, 13(18), 3960. https://doi.org/10.3390/ ma13183960.

6. A Nurul, M., \& Syahrullail, S. (2017). A new approach for cold extrusion process: Dimples indentation on sliding contact surface and palm oil as an alternative lubricant. Scientia Iranica, 24(6), 2875-2886. https://doi.org/10.24200/sci.2017.4248.

7. Nanthakumar, S., Rajenthirakumar, D., \& Avinashkumar, S. (2020). Influence of temperature on deformation behavior of copper during microextrusion process. Proceedings of the Institution of $\mathrm{Me}$ chanical Engineers, Part C: Journal of Mechanical Engineering Science, 234(9), 1797-1808. https://doi.org/10.1177/0954406219899114.

8. Miłek, T., Borys, M., Czyż, Z., Falkowicz, K., Kujawska, J., Kulisz, M., \& Szala, M. (2017). The analysis of distributions of effective strain and flow stress in longitudinal sections of cold backward extruded copper cans for different punch-face shapes. ITM Web of Conferences, 15(10-11), 07014. https://doi.org/10.1051/itmconf/20171507014.

9. Al-Haidary, J., Haddad, J., Alfaqs, F., \& Zayadin, F. (2021). Susceptibility of Aluminum Alloy 7075 T6 to Stress Corrosion Cracking. SAE International Journal of Materials and Manufacturing, 14(2). https://doi.org/10.4271/05-14-02-0013.

10. Mazorchuk, V., Naumova, I., Repyakh, S., \& Sharkova, S. (2018). The stresses in the hollow cylindrical combined castings. Naukovyi Visnyk Natsionalnoho Hirnychoho Universytetu, (3), 94-99. https:// doi.org/10.29202/nvngu/2018-3/9.

11. Qamar, S.Z., Chekotu, J.Ch., \& Qamar, S. B. (2019). Effect of Shape Complexity on Ram Pressure and Metal Flow in Aluminum Extrusion. JOM, 71(1). https://doi.org/10.1007/s11837-019-03748-6. 12. Berndt, N., Frint, P., \& Wagner, M. (2018). Influence of Extrusion Temperature on the Aging Behavior and Mechanical Properties of an AA6060 Aluminum Alloy. Metals, 8(1), 51. https://doi. org/10.3390/met8010051.

13. Ikumapayi, Omolayo M., Oyinbo, Sunday T., Bodunde, Ojo P., Afolalu, Sunday A., Okokpujie, Imhade P., \& Akinlabi, Esther T. (2018). The effects of lubricants on temperature distribution of 6063 aluminium alloy during backward cup extrusion process. Journal of
Materials Research and Technology, 8(1), 1175-1187. https://doi. org/10.1016/j.jmrt.2018.08.006.

14. Lv, J., Hu, F., Cao, Q.D., Hong, X., Dong, X., \& Zhang, X. (2017). Fabrication and Mechanical Characterization of Cold Extruded Aluminum Bronze Planar Microsprings. Journal of Materials Engineering and Performance, 26(6), 2919-2927. https://doi.org/10.1007/ s11665-017-2688-5.

\section{Формулювання функцій сили й тиску для прямої холодної екструзії алюмінієвого сплаву Al 1350 з використанням методу регресії}

\author{
Фаді Альфакс, Газі С. Марахле
}

Кафедра машинобудування, факультет інженерних технологій, Аль-Балка Прикладний університет, м. Амман, Йорданія, e-mail: faalfaqs@bau.edu.jo

Мета. Розробити методологію для математичного визначення як сили екструзії, так і функцій тиску для алюмінієвого сплаву Al 1350 з використанням методу регресії експериментальних даних.

Методика. Кілька змінних (діаметр порожнини для пресування $D$, ступінь видавлювання, кут конуса головки пуансона $2 \delta$ і співвідношення розмірів напівфабрикатів $R_{s}$ ) були включені при використанні розглянутого методу регресії.

Результати. Було встановлено, що діаметр і деформація грають важливу роль у прогнозуванні як сили екструзії, так і функцій тиску, пов'язаних із процесом екструзії. Математичні формули для сили й тиску були отримані 3 використанням методу регресії. Розроблена методологія для математичного визначення сили й тиску.

Наукова новизна. Функції сили й тиску у процесі прямої холодної екструзії в основному потрібні для проектування екструзійних матриць. Однак наявності таких даних у літературі недостатньо для реалізації процесу прямого холодного пресування алюмінію та алюмінієвих сплавів і інших матеріалів. Результати дослідження враховують основні фактори, що впливають на силу й тиск екструзії, а також основні відмінності за типами алюмінієвих сплавів.

Практична значимість. Математичні формули, отримані методом регресії, $є$ математичним інструментом для розрахунку значень сили й тиску у процесі прямої екструзії.

Ключові слова: алюмінієвий сплав, пряма екструзія, сила, тиск, регресія

Recommended for publication by Jamal Jaber, Professor of Mechanical Engineering. The manuscript was submitted 02.04.21. 